\title{
Peranan Ektrakurikuler Pramuka Terhadap Pembentukan Karakter Siswa Di SMA Negeri 4 Binjai
}

\section{Farida Suri}

Universitas Negeri Medan

Corresponding Author: @faridasurifada@gmail.com

\begin{tabular}{ll}
\hline & \multicolumn{1}{c}{ ABSTRACT } \\
\cline { 2 - 3 } & Penelitian ini bertujuan untuk mengetahui peranan kegiatan \\
kepramukaan dalam membentuk karakter siswa SMA Negeri 4 Binjai \\
dan mengetahui faktor penunjang dan penghambat pembentukan \\
karakter melalui kegiatan kepramukaan. Penelitian ini merupakan \\
penelitian deskriptif kualitatif. Subjek penelitian ada 7 orang yaitu guru, \\
pembina pramuka, dan siswa SMA Negeri 4 Binjai. Teknik pengumpulan \\
data menggunakan observasi, wawancara dan dokumentasi. Analisis \\
data yang digunakan adalah reduksi data, menyajikan data, dan \\
menyimpulkan data. Pelaksanaan keabsahan data melalui trianggulasi. \\
& $\begin{array}{l}\text { Hasil penelitian menyimpulkan bahwa; 1. Peranan kegiatan } \\
\text { kepramukaan untuk membentuk karakter siswa yaitu meningkatkan } \\
\text { nilai religius, kedisiplinan, sikap mandiri, cinta tanah air, dan tanggung } \\
\text { jawab. 2. Faktor pendukung pembentukan karakter melalui kegiatan } \\
\text { kepramukaan adalah kerja sama pihak sekolah dengan guru dan } \\
\text { pembina pramuka dalam memberikan contoh atau keteladanan yang } \\
\text { baik kepada siswa, serta minat siswa dalam mengikuti kegiatan } \\
\text { ektrakulikuler pramuka disekolah. Sedangkan faktor penghambat } \\
\text { diantaranya minimnya dana untuk kegiatan kepramukaan dan sarana } \\
\text { prasarana misalnya lapangan tempat latihan. }\end{array}$ \\
\cline { 2 - 3 } Kata Kunci & $\begin{array}{l}\text { Ektrakurikuler, Karakter, Pramuka } \\
\text { Keywords }\end{array}$ \\
How to cite & (2021). Jurnal Ability, 2(4).
\end{tabular}

\section{PENDAHULUAN}

Masalah Pendidikan adalah usaha sadar dan terencana untuk mewujudkan suasana belajar dan proses pembelajaran agar peserta didik sacara aktif mengembangkan potensi dirinya untuk memiliki kekuatan spiritual keagamaan taqwa kepada Tuhan Yang Maha Esa, cinta alam dan kasih sayang sesama manusia, patriot yang sopan dan kesatria, patuh dan suka bermusyawara, rela menolong dan tabah, disiplin, berani dan setia, bertanggungjawab dan suci dalam pikiran, yang diperlakukan bangsa dan negara. Dalam melaksanakan prinsip penyelengggaraan pendidikan kepramukaan harus sesuai dengan dasa darma dan tujuan pendidikan nasional yaitu, mengembangkan kemampuan dan membentuk watak serta peradaban 
Ability : Journal of Education and Social Analysis

Volume 2, Issue 4, Oktober 2021

Page : 42-51

bangsa yang bermartabat dalam rangka mencerdaskan kehidupan bangsa, bertujuan untuk berkembangnya potensi peserta didik agar menjadi manusia yang beriman dan bertakwa kepada TuhanYang Maha Esa, berakhlak mulia, sehat, berilmu, cakap, kreatif, mandiri, dan menjadi warga yang demokratis serta bertanggung jawab.

Istilah karakter sangat sering kita dengar, jika berbicara tentang karakter sama dengan berbicara mengenai kepribadian. Karakter menjadi suatu indentitas bagi individu dan menjadi pembeda pada individu. Karakter dapat dipahami sebagai pembentukan etika dan mental secara kompleks yang membentuk kepribadian seseorang, kelompok, bahkan suatu bangsa.Menurut Thomas Lickona (2013:82), karakter diartikan sebagai sifat alami seseorang dalam merespons situasi secara bermoral. Lickona menekankan tiga hal dalam mendidik karakter, yang dirumuskan dengan baik yaitu: knowing, loving and acting the good.Menurut Pupuh (2013: 18) mengatakan bahwa:Karakter identik dengan akhlak, sehingga karkater merupakan nilai-nilai perilaku manusia yang universal yang meliputi seluruh aktivitas manusia, baik dengan rangka yang berhubungan dengan Tuhannya, dengan dirinya, dengan sesama manusia, maupun dengan lingkungannya, yang terwujud dalam pikiran, sikap, perasaan, perkataan dan perbuatan berdasarkan norma-norma agama, hukum, tata krama, budaya, dan adat istiadat.

Menurut Kemendiknas (2010:9) ada 18 nilai-nilai karakter yang bersumber dari agama, pancasila, budaya dan tujuan pendidikan nasional.Adapun 18 nilai tersebut yaitu:

1. Religius merupakan sikap dan perilaku yang patuh dalam melaksanakan ajaran agama yang dianutnya, toleran terhadap pelaksanaan ibadah agama lain, dan hidup rukun dengan pemeluk agama lain

2. Jujur merupakan perilaku yang didasarkan pada upaya menjadi dirinya sebagai orang yang selalu dapat dipercaya dalam perkataan, tindakan dan pekerjaan

3. Toleransi sikap dan tindakan yang menghargai perbedaan agama, suku, etnis, pendapat, sikap dan tindakan orang lain yang berbeda dari dirinya.

4. Disiplin merupakan tindakan yang menunjukan prilaku tertib dan patuh pada berbagai ketentuan dan peraturan.

5. Kerja keras merupakan perilaku yang menunjukkan upaya sungguhsungguh dalam mengatasi berbagai hambatan belajar ddan tugas serta menyelesaikan tugas dengan sebaik-baiknya.

6. Kreatif dan berfikir dan melakukan sesuatu untuk menghasilkan cara atau hasil baru dari sesuatu yang telah dimiliki. 
Ability : Journal of Education and Social Analysis

Volume 2, Issue 4, Oktober 2021

Page : 42-51

7. Mandiri merupakan sikap dan perilaku yang tidak mudah terganggu pada orang lain dalam menyelesaikan tugas-tugas.

8. Demokratis merupakan cara berfikir, bersikap, dan bertindak yang menilai sama hak dan kewajiban dirinya dan orang lain.

9. Rasa ingin tahu merupakan sikap dan tindakan yang selalu berupaya untuk mengetahui lebih mendalam dan meluas dari sesuatu yang dipelajarinya, dilihat, dan didengar.

10. Semangat kebangsaan merupakan cara berfikir, bertindak, dan berwawasan yang menempatkan kepentingan bangsa dan Negara di atas kepentingan diri dan kelompoknya

11. Cinta Tanah Air merupakan cara berfikir, bersikap dan berbuat yang menunjukkan kesetiaan, keperdulian, dan penghargaan yang tinggi terhadap bahasa, lingkungan fisik, sosial, budaya, ekonomi, dan politik bangsa.

12. Menghargai Prestasi merupakan sikap dan tindakan yang mendorong dirinya untuk menghasilkan sesuatu yang berguna bagi masyarakat, dan mengakui, serta menghormati keberhasilan orang lain.

13. Bersahabat/ Komukatif merupakan tindakan yang memperlihatkan rasa senang berbicara, bergaul, dan bekerja sama dengan orang lain.

14. Cinta Damai merupakan sikap, perkataan, dan tindakan yang menyebabkan orang lain merasa senang dan aman atas kehadiran dirinya

15. Gemar Membaca merupakan kebiasaan menyediakan waktu untuk membaca berbagai bacaan yang memberikan kebajikan bagi dirinya.

16. Peduli Lingkungan merupakan sikap dan tindakan yang selalu berupaya mencegah kerusakan pada lingkungan alam di sekitarnya, dan mengembangkan upaya-upaya untuk memperbaiki kerusakan alam yang sudah terjadi.

17. Peduli Sosial merupakan sikap dan tindakan yang selalu ingim memberikan bantuan pada orang lain dan masyarakat yang membutuhkan.

18. Tanggung Jawab merupakan sikap dan perilaku seseorang untuk melaksanakan tugas dan kewajibannya, yang seharusnya dia lakukan, terhadap diri sendiri, masyarakat, lingkungan (alam, sosial dan budaya), Negara dan Tuhan Yang Mahas Esa.

Menurut Mayor (2008:19) dari 18 karakter tersebut terdapat 6 pilar penting karakter yang disebutkan yaitu: penghormatan, tanggung jawab, kesadaran berwarganegara, keadilan, keperdulian dan kepercayaan. 
Ability : Journal of Education and Social Analysis

Volume 2, Issue 4, Oktober 2021

Page : 42-51

Kebijakan mengenai Kegiatan Ektrakurikuler merupakan bagian dari Kebijakan Departemen Pendidikan dan Kebudayaan Nomor 62 Tahun 2014 tentang kegiatan Ektrakurikuler pada Pendidikan Dasar dan Pendidikan Menengah.Kegiatan Ektrakurikuler merupakan kegiatan yang dilakukan di luar kelas dan di luar pelajaran untuk menumbuh kembangkan potensi sumber daya manusia yang dimiliki peserta didik baik berkaitan dengan ilmu pengetahuan yang maupun untuk membimbing peserta didik dalam mengembangkan potensi dan bakat yang ada dalam dirinya melalui kegiatankegiatan wajib maupun pilihan.

Menurut Anwar (2015:45) Ektrakurikuler adalah sarana untuk pengembangan diri siswa. Banyak program-program atau kegiatan yang membangun kejiwaan diri anak kepada arah yang lebih baik dengan manajemen yang baik.

Ektrakurikuler menurut Asmani (2011:62) adalah kegiatan pendidikan diluar jam mata pelajaran dan pelayanan konseling untuk membantu pengembangan peserta didik sesuai dengan kebutuhan, potensi, bakat, dan minat mereka melalui kegiatan yang secara khusus diselenggarakan oleh pendidik dan atau tenaga kependidikan yang berkemampuan dan berwenang disekolah.Ektrakurikuler merupakan kegiatan pendidik diluar jam pelajaran yang ditunjukkan untuk membantu perkembangan peserta didik sesuai, dengan kebutuhan, potensi, bakat, dan minat mereka melalui kegiatan yang secara khusus diselenggarakan oleh peserta didik dan atau tenaga kependidikan yang berkemampuan dan berkewenangan disekolah (Wiyani, 2013:108)

Berdasarkan pengertian diatas bahwa kegiatan ektrakurikuler merupakan kegiatan yang dilakukan diluar jam pelajaran, yang diharapkan peserta didik mampu membantu meningkatkan bakat, minat, keprbadian, karakter, serta watak siswa yang berguna untuk kehidupan peserta didik dimasa mendatang. Ektrakurikuler tersebut diharapkan berguna untuk mengisi waktu luang setelah selesai jam pelajaran sekolah agar waktu luang siswa tersebut diisi dengan hal-hal yang posistif agar membantu siswa dalam memecahkan masalah kebosanan belajar diruang kelas yang pada akhirnya memicu siswa bersemangat dalam pencapaian prestasi belajar yang baik.

Generasi muda adalah salah satu aset Indonesia pada masa yang akan datang. Bangsa Indonesia harus mampu menempatkan generasinya untuk menjadi pemimpin dimasa mendatang. Hal tersebut harus ada upaya untuk menanamkan nilai-nilai kebangsaan sebagai ciri khas budaya bangsa untuk membedakan dengan orang lain di negera ini. Selain itu adanya budaya lokal yang melekat pada diri peserta didik di sekolah akan mampu memperkuat jati 
Ability : Journal of Education and Social Analysis

Volume 2, Issue 4, Oktober 2021

Page : 42-51

diri sebagai bangsa Indonesia. Sehingga masalah ini merupakan suatu fakta yang tidak boleh diabaikan mengingat pentingnnya sikap nasionalisme dalam memajukan Negara Indonesia. Terkait dengan pembentukan karakter di era global ini salah satu lembaga formal yang ikut bertanggung jawab adalah satuan pendidikan kepramukaan yang turut membantu tugas pendidikan informal. Sekolah dapat dikatakan sebagai rumah kedua. Di sekolah, anak mendapatkan pendidikan akademik, juga mendapatkan pendidikan moral dan spiritual melalui kegiatan kepramukaan. Karena itu sekolah dan kegiatan menjadi salah satu wadah yang tepat untuk menanamkan nilai-nilai kebangsaan kepada peserta didik. Dalam hal ini sekolah dan pembina pramuka mempunyai peran yang sangat penting.

Gerakan Pramuka merupakan salah satu wadah bagi para remaja untuk mengembangkan potensi yang ada dalam dirinya, terutama mengembangkan kepemimpinan yang terdapat dalam dirinya, oleh karena itu para remaja atau pemuda adalah Tulang Punggung Negara. Oleh karena itu para remaja bukan hanya menguasai sebuah ilmu dan teknologi akan tetapi harus juga dipersiapkan menjadi seorang pemimpin yang cerdas, terampil dan tangguh (Agus Zaenal Fitri, 2012:40). Pada saat sekarang, baik di sekolah dasar, menengah pertama, menengah atas, maupun di perguruan tinggi hampir seluruhnya mempunyai organisasi ekstrakulikuler gerakan pramuka dengan tingkatan masing-masing. Makin maraknya organisasi kepramukaan makin tinggi, dengan demikian sekolah-sekolah di indonesia khususnya SMA Negeri 4 Binjai akan berbangga hati karena dengan semakin tingginya minat siswa dan pemuda terhadap orgnisasi kepramukaan maka dengan sendirinya persoalanpersoalan pembentukan karakter itu dapat ditanggulangi.

\section{METODE PENELITIAN}

Metode penelitian ini adalah metode kualitatif. Penelitian ini untuk mengetahui penguatan karakter siswa melalui kegiatan ektrakurikuler di SMA Negeri 4 Binjai. Sebagai upaya untuk memperoleh jawaban dan permasalahan yang ada, maka peneliti menggunakan metode kualitatif.Menurut Nana (2011:60), penelitian kualitatif adalah suatu penelitian yang ditunjukan untuk mendeskripsikan dan menganalisis fenomena, peristiwa, aktifitas sosial, sikap, kepercayaan, persepsi, pemikiran orang lain secara indivial atau pun kelompok.

Sedangkan menurut Djunaidi (2014:25), penelitian kualitatif adalah penelitian yang menghasilkan penemuan-penemuan yang tidak dapat dicapai dengan menggunakan prosedur statistik atau dengan cara-cara kuantifikasi. Penelitian kualitatif dapat menunjukan kehidupan masyarakat, sejarah, 
Ability : Journal of Education and Social Analysis

Volume 2, Issue 4, Oktober 2021

Page : 42-51

tingkah laku, fungsionalisasi organisasi, pergerakan nasional, dan hubungan kekerabatan.Hubungan kualitatif ini mengacu pada proses pelaksanaan dilapangan, bisa dilaksanakan dengan opservasi langsung, opservasi partisipan, wawacara mendalam, dokumen-dokumen,foto-foto maupun rekaman suara dan data lain yang dapat menunjang keberlangsungan dalam penelitian ini supaya mendapatkan data yang valid.

Diharapkan dengan menggunakan metode penelitian ini, penulis dapat mengetahui gambaran bagaimana penguatan karakter siswa melalui kegiatan ektrakurikuler di SMA Negeri 4 Binjai dengan berfokus kepada tiga karakter yaitu disiplin, tanggung jawab, dan religius.

Kerangka berfikir merupakan alur berfikir yang dapat menjelaskan secara garis besar yang mengenai penelitian yang dapat memudahkan pembaca dalam memahami penelitian ini. Adapun kerangka berfikir yaitu sebagai berikut:

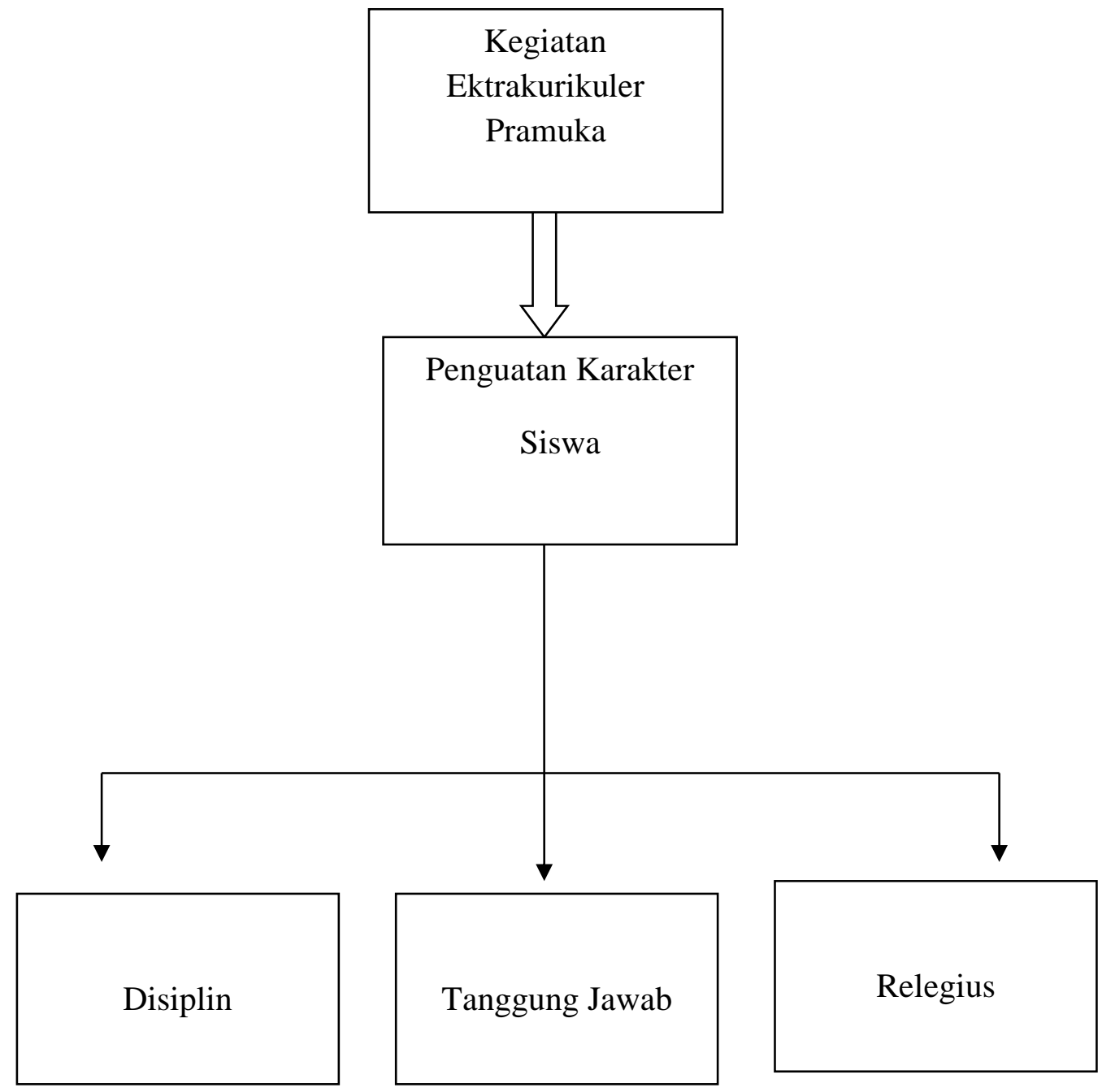


Ability : Journal of Education and Social Analysis

Volume 2, Issue 4, Oktober 2021

Page : 42-51

\section{HASIL DAN PEMBAHASAN}

Penelitian ini bertujuan untuk mengetahui peranan kegiatan kepramukaan dalam membentuk karakter siswa SMA Negeri 4 Binjai dan mengetahui faktor penunjang dan penghambat pembentukan karakter melalui kegiatan kepramukaan. Penelitian ini merupakan penelitian deskriptif kualitatif. Subjek penelitian ada 7 orang yaitu guru, pembina pramuka, dan siswa SMA Negeri 4 Binjai. Teknik pengumpulan data menggunakan observasi, wawancara dan dokumentasi. Analisis data yang digunakan adalah reduksi data, menyajikan data, dan menyimpulkan data. Pelaksanaan keabsahan data melalui trianggulasi. Hasil penelitian menyimpulkan bahwa; 1. Peranan kegiatan kepramukaan untuk membentuk karakter siswa yaitu meningkatkan nilai religius, kedisiplinan, sikap mandiri, cinta tanah air, dan tanggung jawab. 2. Faktor pendukung pembentukan karakter melalui kegiatan kepramukaan adalah kerja sama pihak sekolah dengan guru dan pembina pramuka dalam memberikan contoh atau keteladanan yang baik kepada siswa, serta minat siswa dalam mengikuti kegiatan ektrakulikuler pramuka disekolah.

Sedangkan faktor penghambat diantaranya minimnya dana untuk kegiatan kepramukaan dan sarana prasarana misalnya lapangan tempat latihan. Kegiatan kepramukaan merupakan kegiatan yang diberikan kepada peserta didik di lembaga pendidikan yang bertujuan untuk menonjolkan potensi diri yang belum terlihat di luar kegiatan belajar mengajar,memperkuat potensi yang telah dimiliki peserta didik. Kegiatan kepramuka yang ada di SMA Negeri 4 Binjai telah didirikan pada tahun 2009. Latar belakang diterapkannya kegiatan pramuka di SMA Negeri 4 Binjai bertujuan untuk membentuk karakter siswa. Dengan diadakan kegiatan pramuka diharapkan dapat merubah perilaku amoral yang dilakukan peserta didik pada saat sekarang ini. Pendidikan pramuka merupakan hal terpenting dalam membentuk karakter bukanlah berarti bahwa pendidikan yang lainnya tidaklah penting untuk dipelajari. Peran pendidikan kepramukaan dalam membentuk karakter siswa diibaratkan kawah candradimuka bagi generasi muda, caloncalon pemimpin masa depan Indonesia.Gerakan kepramukaan merupakan salah satu wadah dan usaha untuk pembinaan karakter generasi mudah dengan menggunakan pendidikan kepramukaan yang pelaksanaannya diserasikan dengan keadaan, kepentingan, dan perkembangan siswa serta masyarakat Indonesia. Terkait pembentukan karakter hal yang harus diperhatikan dikembangkan pramuka dapat membangun akhlak anak bangsa yang baik, berbudi pekerti, berpikir positif, tangguh, percaya diri, disiplin, tanggungjawab, kebersamaan hingga kemandirian. 
Ability : Journal of Education and Social Analysis

Volume 2, Issue 4, Oktober 2021

Page : 42-51

Derasnya arus globalisasi menyebabkan betapa pentingnya nilai-nilai gerakan pramuka menuju bangsa yang maju yang berkaitan langsung dengan pembentukan karakter adalah membangun peradaban bangsa yang berakhlak mulia adalah membangun karakter siswa. Pembentukan karakter itu bisa dilakukan dengan kegiatan ekstrakulikuler pramuka seperti ketrampilan dalam baris-berbaris, kepemimpinan, bertanggungjawab dan kedisiplinan. Menerapkan program kegiatan pramuka dalam membentuk karakter siswa bukan hanya sebagai pelengkap semata, akan tetapi pramuka dapat berpengaruh terhadap proses belajar mengajar anak. karena pramuka sebagai salah satu wadah positif untuk membangkitkan rasa percaya diri anak, kepedulian, kebersaan dan kemandirian. Dengan adanya kegiatan pramuka siswa akan mendapat hal-hal baru seperti belajar berorganisasi, kerja sama dan kemandirian.

Kegiatan pramuka sangat bermanfaat dalam membentuk karakter anak. karena pendidikan dapat membangun kecerdasan, dan kepribadian anak menjadi manusia yang lebih baik. Allah berfirman dalam Al-Quran. Surat AlAhzab ayat 21. Artinya : sungguh, telah ada pada (diri) Rasullah itu suri teladan yang baik bagi (yaitu) Allah dan (kedatangan) hari kiamat dan yang banyak mengingat Allah (Abd Azis Albone, 2006:45). Pelajar merupakan generasi penerus bangsa, yang diharapkan di masa depan mampu meneruskan bangsa ini menjadi lebih baik. Untuk mewujudkan generasi penerus bangsa yang baik dibutuhkan peran dari berbagai unsur sekolah, keluarga, masyarakat, dan negara. Keseluruhan bertanggung jawab membentuk kepribadian yang baik pada pelajar. Pendidikan karakter saat ini menjadi fokus program Kementrian Pendidikan Nasional. Oleh karena itu pemerintah terus berupaya untuk melakukan pengembangan pendidikan yang dapat mengantisipasi kaum muda agar mereka memiliki watak dan karakter yang sesuai dengan budaya bangsa Indonesia. Pendidikan ektrakulikuler pramuka sebagai solusi pemerintah untuk pengembangan kurikulum yang mengacu kepada pembentukan karakter ( Elly Sri Melinda, 2013:12).

Melalui pendidikan kepramukaan, siswa sejak dini dilatih untuk menumbuhkan kedisiplinan yang baik. Rangkaian kegiatan kepramukaan, misalnya kegiatan upacara, Peraturan Baris-Berbaris (PBB) sarat dengan penanaman disiplin. Setiap kegiatan yang dijalani melatih siswa untuk senantiasa mentaati aturan dan tata tertib yang ada. Kegiatan kepramukaan mempunyai peran yang penting dalam menata perilaku membentuk karakter siswa melalui pembiasaan yang dilakukan pada setiap kesempatan. Dari uraian diatas dapat diketahui bahwa kepramukaan merupakan salah satu pendidikan ekstrakurikuler wajib yang sangat tepat untuk siswa sekolah SMA. Maka 
Ability : Journal of Education and Social Analysis

Volume 2, Issue 4, Oktober 2021

Page : 42-51

tidaklah mengherankan apabila dalam Permendikbud No. 62 Tahun 2014 tentang Kegiatan Ekstrakurikuler menempatkan pendidikan kepramukaan sebagai ekstrakurikuler wajib di sekolah. Salah satu sekolah menengah pertama di Binjai yang menerapkan pendidikan kepramukaan adalah SMA Negeri 4 Binjai.

Menurut observasi yang sebelumnya telah dilakukan peneliti, kegiatan kepramukaan yang diselenggarakan di SMA Negeri 4 Binjai terbilang bagus. Hal ini dapat dibuktikan dari prestasi yang pernah diraih dibidang kepramukaan. Salah satu prestasi tersebut adalah mendapatkan juara pertama untuk lomba Gitapanitra antar sekolah di Binjai pada tahun 2021. Peran kegiatan kepramukaan sebagai salah satu upaya yang dilakukan dalam rangka membentuk karakter siswa khususnya siswa SMA Negeri 4 Binjai. Dengan masalah yang dipaparkan tersebut, itulah latar belakang penyusun memilih judul skripsi "Peranan Kegiatan Kepramukaan Dalam Membentuk Krakter Siswa SMA Negeri 4 Binjai

\section{KESIMPULAN}

Berdasarkan hasil penelitian diperoleh kesimpulan Pendidikan Kepramukaan adalah pendidikan non formal yang menunjang pendidikan formal di sekolah dan pendidikan informal dan keluarga yang bertujuan untuk pengembangan watak dan karakter peserta didik. Dengan melalui berbagai gerakan atau berbagai kegiatan dalam pendidikan kepramukaan bertujuan untuk membina kaum muda Indonesia guna mengembangkan mental, spiritual, emosional, sosial, intelektual dan fisik sehingga menjadi manusia yang berkepribadian, menjadi warga masyarakat yang baik dapat membangun dirinya sendiri secara mandiri dan bersama-sama bertanggun jawab dalam pembangunan bangsa dan negara.

Gerakan pramuka merupakan salah satu lembaga pendidikan nonformal yang mempunyai tugas pokok menyelenggarakan pendidikan kepramukaan bagi anak-anak dan pemuda Indonesia. Pendidikan kepramukaan melatih peserta didiknya untuk menjadi generasi penerus yang mandiri, memiliki disiplin tinggi, budi pekerti luhur, mampu membangun masyarakat serta berguna bagi bangsa dan negara. Nilai-nilai kepramukaan bersumber dari satya pramuka, darma pramuka, serta kecakapan dan keterampilan yang dikuasai anggota pramuka. Satya Pramuka merupakan kode kehormatan bagi setiap anggota pramuka yang menunjukkan nilai ketuhanan, sikap nasionalisme dan solidaritas. Darma pramuka merupakan kode moral, janji dan komitmen diri yang wajib dihafal dan diamalkan oleh setiap anggota pramuka agar memiliki kepribadian baik. Sementara itu kecakapan dan keterampilan diajarkan dalam 
Ability : Journal of Education and Social Analysis

Volume 2, Issue 4, Oktober 2021

Page : 42-51

kegiatan kepramukaan agar nantinya dapat berguna ketika hidup di masyarakat dan di alam.

\section{REFERENCES}

Arikunto, Suharsimi, 2006. Prosedur Penelitian Suatu Pendekatan Praktik. Jakarta: Rineka Cipta. Global). Jakarta : Grasindo

Andri Bob, Sunardi. 2010. Boyman Ragam Latihan Pramuka. Bandung : Nuansa Bunda

Hidayatullah, Furqon. 2010. Pendidikan Karakter: Membangun Peradapan Bangsa. Surakarta: Yuma Pustaka

Istarani. 2012. Kurikulum Sekolah Berkarakter. Medan : Media Persada.

Jana T Anggadiredja, dkk. 2011. Kursus Mahir Lanjutan untuk Pembina Pramuka: Golongan Penggalang, Jakarta: Kwartir Nasional Gerakan Pramuka.

Kesuma, Dharma dkk. 2012. Pendidikan Karakter: Kajian Teori dan Praktik di Sekolah. Bandung: Remaja Rosdakarya

Koesoema. A, Doni. 2010. Pendidikan Karakter (Strategi Mendidik Anak di Jaman Global). Jakarta: PT Grasindo

Mangunhardjana, A. 1986. Pembinaan, Arti dan Metodenya. Yogyakarta: Kanisius Muslich, Masnur. 2011. Pendidikan Karakter (Menjawab Tantangan Krisis Multidimensional). Jakarta : Bumi Aksara.

Novan Ardy, Wiyani. 2012. Pendidikan Karakter dan Kepramukaan. Yogyakarta : Citra Aji Parama

Purwanto. 2011. Evaluasi hasil Belajar. Yogyakarta : Pustaka Belajar

Simanjuntak, B,. I. L Pasaribu. 1990. Membina dan Mengembangkan Generasi Muda. Bandung: Tarsito

Suryo Subroto. 2002. Proses Belajar Mengajar di Sekolah. Jakarta: PT Rineka Cipta

Sutikno, dkk. 2011. Buku Kursus Pembina Pramuka : Mahir Tingkat Dasar. Yogyakarta : Penerbit Andi

Suyadi. 2013. Strategi Pembelajaran Pendidikan Karakter. Bandung: Remaja Rosdakarya 